\title{
The influence of Schiff base inclusion complexes with $\beta$-cyclodextrine on antibiotic production by Streptomyces hygroscopicus $\mathrm{CH}-7$
}

\author{
Slavica B. Ilić ${ }^{1}$, Sandra S. Konstantinović ${ }^{1}$, Gordana Gojgić-Cvijović ${ }^{2}$, Dragiša S. Savić ${ }^{1}$, Vlada B. Veljković ${ }^{1}$ \\ ${ }^{1}$ Faculty of Technology, University of Niš, Leskovac, Serbia \\ ${ }^{2}$ Department of Chemistry, ICTM, University of Belgrade, Belgrade, Serbia
}

\begin{abstract}
A media consisting of isatin-Schiff bases and its inclusion complexes with $\beta$-cyclodextrine was developed to maximize the production of antibiotics Hexaene $\mathrm{H}-85$ and azalomycine $\mathrm{B}$ by Streptomyces hygroscopicus $\mathrm{CH}-7$. The media with $\beta$-cyclodextrine inclusion complex of isatin-3-thiosemicarbazone resulted in the maximum antibiotics concentration of 493 $\mu \mathrm{g} / \mathrm{cm}^{3}$ for Hexaene $\mathrm{H}-85$ and $191 \mu \mathrm{g} / \mathrm{cm}^{3}$ for azalomycine $\mathrm{B}$. The production of hexaene $\mathrm{H}-85$ and azalomycine is higher when $\beta$-cyclodextrine complex is added as a nitrogen source, comparing to pure isatin-Schiff base. The maximum concentration of hexaene $\mathrm{H}-85$ in medium with inclusion complex of isatin-Schiff base is 1.4-2.3 times higher than the basal medium. The maximum production of azalomycine is 2.1-3.4 times higher in media with inclusion complex of Schiff base. During the fermentation process, the nutrient media with $\beta$-cyclodextrine inclusion complexes with isatin-Schiff bases affect the strain morphology, since it is in the form of compact pellets, which are formed from short and long, branched filaments.
\end{abstract}

Keywords: Streptomyces hygroscopicus, Schiff base, $\beta$-cyclodextrine, inclusion complex, antibiotic production.

SCIENTIFIC PAPER

UDC 579.66:602.4:615.3:54

Hem. Ind. 69 (1) 9-15 (2015)

doi: 10.2298/HEMIND131113012I

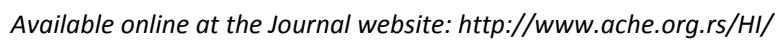

Actinomycetes, especially Streptomyces bacteria are extremely important group of microorganisms because of their ability to produce commercially important secondary metabolites [1,2]. Actinomycetes name comes from the Greek word "aktis" which means air and "mikes" which means mushroom. The smell of soil that occurs immediately after the rain just comes from actinomycetes, precisely from geosmin, streptomycetes metabolite [3].

Most antibacterial and antifungal agents, now in clinical use, were found during the "golden era" of antibiotics in forties and sixties of $20^{\text {th }}$ century, by isolation and screening of soil fungi and actinomycetes. During this period, nearly 12,000 of bioactive secondary metabolites were discovered, of which 160 is used for clinical purposes such as natural, as well as semisynthetics products. $55 \%$ of discovered secondary metabolites were produced by the genus Streptomyces, $11 \%$ from other actinomycetes, $12 \%$ of non-filamentous bacteria and $22 \%$ of filamentous fungi [4].

Penicillins, cephalosporins, tetracyclines, aminoglycosides, glycopeptides, macrolides and polyenes discovered in time of the "golden era" still represent very important antibiotics against bacterial and fungal infections. Between sixties and eighties of $20^{\text {th }}$ century,

Correspondence: S.B. Ilić, Faculty of Technology, University of Niš, Bulevar oslobodjenja 124, 16000 Leskovac, Serbia.

E-mail: ilicslavica@yahoo.com

Paper received: 13 November, 2013

Paper accepted: 20 February, 2014 the pharmaceutical efforts have been directed towards improving existing chemo types, increasing potency, stability and pharmacokinetics.

However, despite significant advances in technology and the development of methods and instruments in the field of microbiological screening, the last twenty years have been without significant breakthroughs in terms of antibiotics. Actually, a small number of new drugs act selectively and often do not penetrate the microbial pathogen cell, or even deactivated in vivo. As a matter of fact, over the past few decades, antibacterial lipopeptides - daptomycins produced by Streptomyces roseosporus (active against Gram-positive bacteria that cause skin infections) and cyclic lipopeptides - echinocandins and pneumocandins (which inhibit the biosynthesis of fungal cell walls) can be considered significant [4].

Great ability of Streptomyces to produce antibiotics makes streptomycetes interesting for study, but old methods of screening these organisms should be modernized and some new should be introduced. Isolation must be made by, at least, unusual habitats, assuming that unknown types of endophytes, extremephiles or marine streptomycetes can produce new chemotypes.

Among them, abyssomicin $C$ presents a new polycyclic and polyketide antibiotic produced by a marine strain Verrucosispora and it is very active against Gram-positive bacteria [5]. Diazepinomicin is a unique dibenzodiazepinon produced by a strain of Micromonospora 
[6] known for its antibacterial, antiinflammatory and antitumor activities. Salinosporamide $A$ is a new $\beta$-lactone- $\gamma$ lactam isolated from the fermentation broth of marine actinomycetes Salinispora tropical [7].

It is also possible to reinvestigate antibiotics which activity is yet unknown. For example, early discovered antibiotic plantensimycin produced by Streptomyces plantesis is found to be an inhibitor of biosynthesis of certain fatty acids. Additional strategies in the discovery of new metabolites could be the study of genomes and detection of cryptic genes encoding secondary metabolism. Genome sequences of Streptomyces coelicolor, S. avermitilis, S. griseus and Saccharopolyspora showed that a large number of biosynthetic gene clusters contain all genes for the production, regulation, transportation and autorezistance of secondary metabolites [4].

Although this selective isolation method is so far allowed for the isolation of a large number of rare actinomycetes, the main problem still is difficult cultivation of rare actinomycetes and complicated genetic engineering [4].

The species Streptomyces hygroscopicus produces a various polyene antibiotics depending on environmental and nutritional conditions [8,9]. The production of antibiotics is usually affected by different parameters, such as chemically defined media. Species of the genus Streptomyces produce antibiotics and growth on substrates with different sources of carbon and nitrogen [10-12]. An increase of the yield of antibiotics can be achieved at an early stage of fermentation conditions and changes in the composition of culture medium $[13,14]$. In the present work, an extensive study has been made on the isatin-Schiff bases and their $\beta$-cyclodextrine inclusion complexes as a nitrogen source in chemically defined media for antibiotic production by $S$. hygroscopicus, as well as, on soil morphology.

\section{MATERIALS AND METHODS}

\section{Bacterial strain, media and growth condition}

A strain Streptomyces hygroscopicus $\mathrm{CH}-7$ (NCAIM (P) B-001336) was gained from Microbial collection at Faculty of Chemistry and Institute of Chemistry, Technology and Metalurgy in Belgrade, Serbia $[3,4]$. S. hygroscopicus was maintained as spore and mycelia suspensions in sterile glycerol $(20 \% \mathrm{w} / \mathrm{V})$, which were prepared according to our previous work $[13,14]$. Suspensions were stored at $-20{ }^{\circ} \mathrm{C}$ until required. The fermentation media were inoculated with $5 \%(\mathrm{~V} / \mathrm{V})$ of a preculture after $48 \mathrm{~h}$ growth and incubated at $30{ }^{\circ} \mathrm{C}$ for $240 \mathrm{~h}$ under the standard condition of aeration and agitation (200 rpm). The fermentation basal media has the following composition: glycerol $15 \mathrm{~g} / \mathrm{dm}^{3}, \mathrm{CaCO}_{3} 3$ $\mathrm{g} / \mathrm{dm}^{3}, \mathrm{NaCl} 3 \mathrm{~g} / \mathrm{dm}^{3}, \mathrm{MgSO}_{4} 0.5 \mathrm{~g} / \mathrm{dm}^{3},\left(\mathrm{NH}_{4}\right)_{2} \mathrm{HPO}_{4} 0.5$ $\mathrm{g} / \mathrm{dm}^{3}, \mathrm{~K}_{2} \mathrm{HPO}_{4} 0.5 \mathrm{~g} / \mathrm{dm}^{3}$ and soya bean $10 \mathrm{~g} / \mathrm{dm}^{3}$. The fermentation modified media has the follow composition: glycerol $15 \mathrm{~g} / \mathrm{dm}^{3}, \mathrm{CaCO}_{3} 3 \mathrm{~g} / \mathrm{dm}^{3}, \mathrm{NaCl} 3 \mathrm{~g} / \mathrm{dm}^{3}$, $\mathrm{MgSO}_{4} 0.5 \mathrm{~g} / \mathrm{dm}^{3},\left(\mathrm{NH}_{4}\right)_{2} \mathrm{HPO}_{4} 0.5 \mathrm{~g} / \mathrm{dm}^{3}, \mathrm{~K}_{2} \mathrm{HPO}_{4} 0.5$ $\mathrm{g} / \mathrm{dm}^{3}$ and inclusion complex $10 \mathrm{~g} / \mathrm{dm}^{3}$.

\section{Determination of antibiotics}

Antibiotics were measured by Perkin-Elmer Lambda 15 UV/Vis spectrophotometer.

\section{Determination of hexaene $\mathrm{H}-85$}

Hexaene $\mathrm{H}-85$ was measured spectrophotometrically at $\lambda=364 \mathrm{~nm}$. The mixture of $0.5 \mathrm{~cm}^{3}$ fermentation broth and $2.0 \mathrm{~cm}^{3}$ of 1-butanol was stirred and centrifugated. Absorbance $(A)$ of 1-butanol extract was measured with 1-butanol as a control probe. The calculation was done by using the following equation:

$\gamma\left(\mu \mathrm{g} / \mathrm{cm}^{3}\right)=66.7 A_{364}$

where 66.7 is experimental calculated extinction coefficient for hexaene $\mathrm{H}-85$ which is $E_{1 \mathrm{~cm}}^{1 \%}=600$ [9].

\section{Determination of azalomycine $B$}

Azalomycine $B$ was measured spectrophotometrically at $\lambda=252 \mathrm{~nm}$. The mixture of $0.5 \mathrm{~cm}^{3}$ fermentation broth and $2.0 \mathrm{~cm}^{3}$ of ethyl acetate was stirred and centrifugated. Absorbance of ethyl acetate extract was measured with ethylacetate as a control probe. The calculation was done by using the following equation:

$\gamma\left(\mu \mathrm{g} / \mathrm{cm}^{3}\right)=25.3 A_{252}$

where 25.3 is experimental calculated extinction coefficient for azalomycine B which is $E_{1 \mathrm{~cm}}^{1 \%}=790$ [15].

Growth was determined by measuring dry weights of cells. The broth was centrifuged at 4000 rpm for 15 $\mathrm{min}$ to separate the mycelial biomass. After that biomass was dried at $105{ }^{\circ} \mathrm{C}$ to constant weight and weighed.

\section{General procedure for isatin-Schiff base}

Equimolar amounts of isatin and thiosemicarbazide, semicarbazide and phenylhydrazine were dissolved in $95 \%$ ethanol. The solutions were heated under reflux for about $50 \mathrm{~min}[16,17]$.

\section{General procedure for $\beta$-cyclodextrine inclusion complexes}

Equimolar amounts of Schiff base and $\beta$-cyclodextrine (Merck, Dermstadt) were dissolved in $150 \mathrm{~cm}^{3}$ distilled water. The solutions were stirred at room temperature for $24 \mathrm{~h}$, concentrated at $50{ }^{\circ} \mathrm{C}$ to about 20 $\mathrm{cm}^{3}$ and dried in vacuum over concentrated $\mathrm{H}_{2} \mathrm{SO}_{4}$.

\section{Methods}

The melting points were determined by using Thomas-Hoover melting point apparatus and are uncor- 
rected. FTIR spectra were recorded using a Michaelson Bomen $\mathrm{MB}$-series spectrophotometer, using $\mathrm{KBr}$ pellet (1 mg/100 mg) technique. The electronic spectra were recorded on a Perkin/Elmer Lambda 15 UV/Vis spectrophotometer using $10^{-3} \mathrm{~mol} / \mathrm{dm}^{3}$ solutions in DMF. The results of identification of Schiff bases are given in previous work [13].

\section{RESULTS AND DISCUSSION}

Schiff bases possess high biological activity, which is greater if their synthesis have been performed by using active component. Schiff bases have antibacterial, antifungal, antimicrobial, anti-HIV, anti-inflammatory and antitumor activity $[16,17]$. Some of them are natural analogues of amino acids, such as isatin-3-thiosemicarbazone analogue of tryptophan, so the positive effect of these compounds on the production of antibiotics is quite expected.

The identification and characterization of synthesized of $\beta$-cyclodextrine inclusion complexes with isatin-Schiff base were done by using standard analytical methods.

\section{Inclusion complex of $\beta$-cyclodextrine and isatin-3-thio- semicarbazone $(\beta$-CD+ITC)}

Yield, 85.9\%, m.p. $134{ }^{\circ} \mathrm{C}$, Color: pale yellow. IR $(\mathrm{KBr}, 1 / \mathrm{cm}): 1667 v(\mathrm{C}=\mathrm{O}), 1585 \vee(\mathrm{C}=\mathrm{N}), 1238 v(\mathrm{C}=\mathrm{S})$. UV/Vis (DMF, $\lambda\left(\mathrm{nm} / \varepsilon \times 10^{3}\left(\mathrm{dm}^{3} \cdot \mathrm{cm} / \mathrm{mol}\right): 200 / 3.784\right.$ $\pi \rightarrow \pi^{*}, 250.0 / 1.187 \pi \rightarrow \pi^{*}, 348.4 / 0.813 \pi \rightarrow \pi^{*}$.

\section{Inclusion complex of $\beta$-cyclodextrine and isatin-3- -semicarbazone $(\beta$-CD+ISC)}

Yield, 80.9\%, m.p. $131{ }^{\circ} \mathrm{C}$, Color: pale yellow. IR $(\mathrm{KBr}, 1 / \mathrm{cm}): 1690,1668 \mathrm{v}(\mathrm{C}=\mathrm{O})$. UV/Vis (DMF, $\lambda(\mathrm{nm} /$ $/ \varepsilon \times 10^{3}\left(\mathrm{dm}^{3} \cdot \mathrm{cm} / \mathrm{mol}\right): 195,0 / 4,286 \pi \rightarrow \pi^{*}, 220 / 4.776$ $\pi \rightarrow \pi^{*}, 265 / 3.791 \pi \rightarrow \pi^{*}, 330 / 2.988 \pi \rightarrow \pi^{*}$.

\section{Inclusion complex of $\beta$-cyclodextrin and isatin-3-phe- nylhydrazone ( $\beta$-CD+IPH)}

Yield, $45.54 \%$, m.p. $136{ }^{\circ} \mathrm{C}$, Color: pale yellow. IR $(\mathrm{KBr}, 1 / \mathrm{cm}): 1666 \mathrm{~V}(\mathrm{C}=0)$. UV/Vis (DMF, $\lambda\left(\mathrm{nm} / \varepsilon \times 10^{3}\right.$ $\left(\mathrm{dm}^{3} \cdot \mathrm{cm} / \mathrm{mol}\right): 195 / 3.125 \pi \rightarrow \pi^{*}, 250 / 0.621 \pi \rightarrow \pi^{*}$, 300/0.349 $\pi \rightarrow \pi^{*}, 385 / 0.212 \pi \rightarrow \pi^{*}$.
Schiff base as a source of nitrogen in a nutrition media has a significant impact on the production of antibiotics [13].

Isatin-3-thiosemicarbazone, isatin-3-semicarbazone, and isatin-3-phenylhydrazone significantly affect production of hexaene $\mathrm{H}-85$ and azalomycine $\mathrm{B}$ using strains of S.hygroscopicus $\mathrm{CH}-7$.

$\beta$-Cyclodextrine has a significant effect on the production of antibiotics by some microorganisms. Addition of this compound in the substrate has a stimulating effect on the production of lankacidin (macrocyclic antibiotic groups) using a microorganism Streptomyces roche var.volubilis, and does not increase microbial growth and is not used as a carbon source $[18,19]$.

The production of hexaene $\mathrm{H}-85$ and azalomycine $\mathrm{B}$ by $\mathrm{S}$. hygroscopicus $\mathrm{CH}-7$ was observed when the soya bean $\left(10 \mathrm{~g} / \mathrm{dm}^{3}\right)$ in basal medium was replaced with inclusion complexes of $\beta$-cyclodextrine with isatin Schiff bases $\left(10 \mathrm{~g} / \mathrm{dm}^{3}\right)$ as a nitrogen source. The maximum concentrations of hexaene $\mathrm{H}-85$ and azalomycine $\mathrm{B}$ and dry biomass, achieved during the fermentation are given in Table 1.

Maximum microbial growth on all substrates is achieved from the second to the fourth day of fermentation (Figure 1b). Maximum concentrations of dry biomass on substrates with inclusion complexes of Schiff bases and pure $\beta$-cyclodextrine were lower than in the basic medium.

The $\mathrm{pH}$ values in all modified media achieved maximum at $3^{\text {rd }}$ day of fermentation (Figure 1a). As it can be seen (Table 1), the maximum concentration of dry biomass (Figure $1 \mathrm{~b}$ ) is reached by $4^{\text {th }}$ day of fermentation in all media. The best result among the tested $\beta$-cyclodextrine inclusion complexes is obtained for the medium with inclusion complex of ITC $\left(8.7 \mathrm{~g} / \mathrm{dm}^{3}\right)$. The maximum concentration of dry biomass in basal medium is reached by $3^{\text {th }}$ day and its value is $8.9 \mathrm{~g} / \mathrm{dm}^{3}$.

\section{Production of hexaene $\mathbf{H}-85$}

The addition of $\beta$-cyclodextrine inclusion complexes with Schiff bases has the significant influence on the production of hexaene $\mathrm{H}-85$. Maximum concentration of antibiotic is reached by $2^{\text {th }}$ day in basal medium and by $2^{\text {th }}$ (pure $\beta$-cyclodextrine and inclusion complex of

Table 1. The impact of inclusion complexes on maximum concentration of dry biomass $\left(X_{\max }\right)$ and maximum production $\left(C_{\max }\right)$ and yield of antibiotics $\left(Y_{\max }\right)$ during the fermentation of S. hygroscopicus $\mathrm{CH}-7$

\begin{tabular}{|c|c|c|c|c|c|}
\hline \multirow[b]{2}{*}{ Nitrogen source } & \multirow[b]{2}{*}{$\begin{array}{c}X_{\max } \\
\mathrm{g} / \mathrm{dm}^{3}\end{array}$} & \multicolumn{2}{|c|}{ Hexaene H-85 } & \multicolumn{2}{|c|}{ Azalomycine B } \\
\hline & & $\begin{array}{c}C_{\text {max }}^{\mathrm{H}} \\
\mu \mathrm{g} / \mathrm{cm}^{3}\end{array}$ & $\begin{array}{c}Y_{\text {max }}^{H} \\
\mu g / g_{s . b}\end{array}$ & $\begin{array}{c}C_{\text {max }}^{A} \\
\mu \mathrm{g} / \mathrm{cm}^{3}\end{array}$ & $\begin{array}{c}Y_{\text {max }}^{A} \\
\mu g / g_{s . b}\end{array}$ \\
\hline Soya bean & 8.9 & 212 & 23.82 & 56 & 6.29 \\
\hline $\mathrm{ITC}+\beta-\mathrm{CD}$ complex & 8.7 & 493 & 56.66 & 191 & 21.95 \\
\hline ISC $\beta$-CD complex & 8.4 & 314 & 37.38 & 123 & 14.64 \\
\hline $\mathrm{IPH} \beta$-CD (complex) & 8.0 & 417 & 52.12 & 136 & 17.00 \\
\hline$\beta-\mathrm{CD}(1 \%)$ & 8.2 & 272 & 33.17 & 102 & 12.43 \\
\hline
\end{tabular}




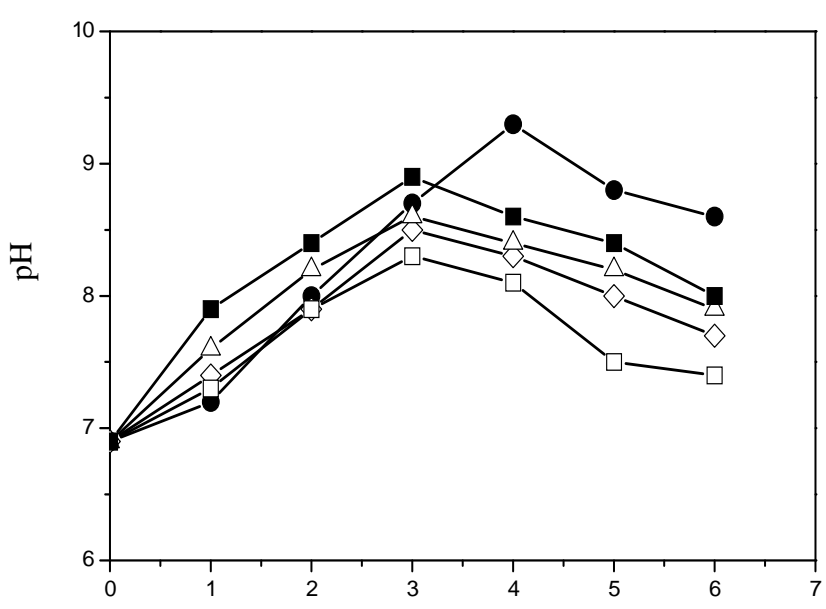

Day of fermentation

(a)

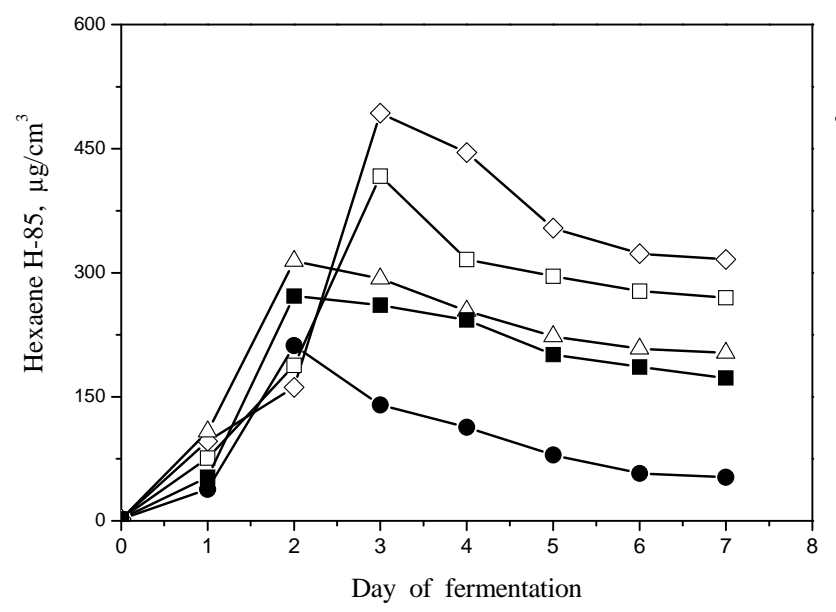

(c)

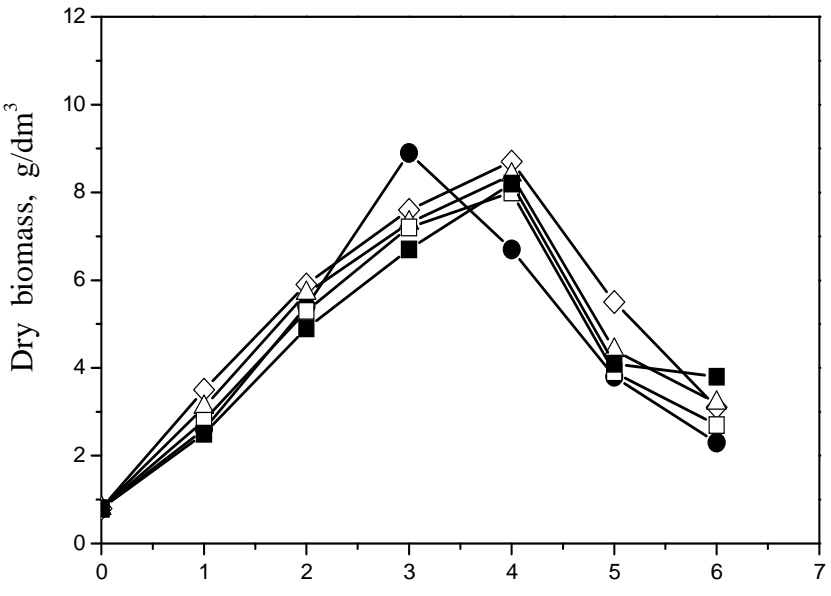

Day of fermentation

(b)

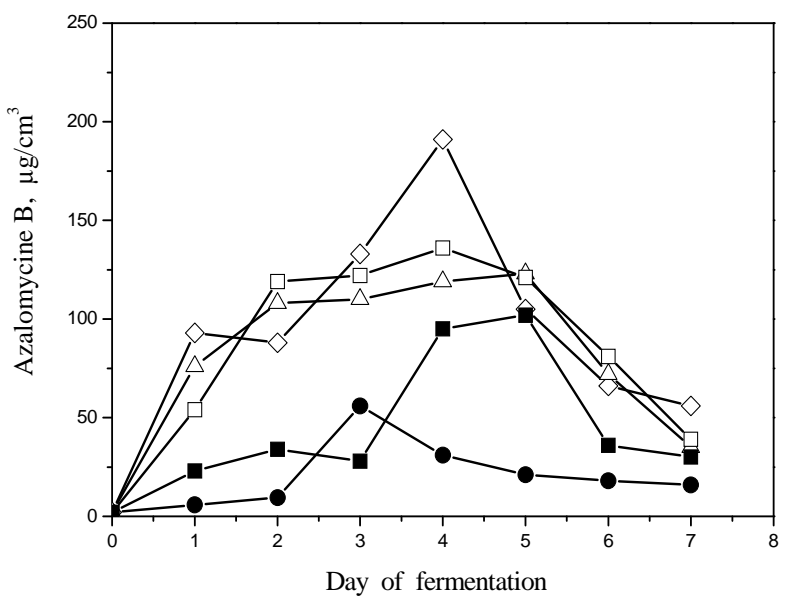

(d)

Figure 1. The change of $\mathrm{pH}(a)$, concentration of dry biomass (b), concentration of hexaene $\mathrm{H}-85$ (c) and azalomycine $B(d)$ in basal medium (-•-), in medium with pure $\beta$-cyclodextrine (---) and media with $\beta$-cyclodextrine inclusion complexes with: ITC (- - -), ISC (- $\Delta-)$ and IPH (-口-).

ISC) and $3^{\text {th }}$ (inclusion complex of ITC and IPH) day in modified media (Figure 1).

The maximum concentration of hexaene $\mathrm{H}-85$ in medium with inclusion complex of ITC, ISC and IPH is 2.3, 1.4 and 1.9 times higher than the basal medium $\left(212 \mu \mathrm{g} / \mathrm{cm}^{3}\right)$. It can be seen (Table 1$)$, that the concentration of hexaene $\mathrm{H}-85$ in medium with pure $\beta$-cyclodextrine is also 1.2 times higher than in the basal medium.

\section{Production of azalomycine B}

The production of Azalomycine B is also stimulated in media with $\beta$-cyclodextrine inclusion complexes with Schiff bases. Maximum concentration of antibiotic is reached by $3^{\text {th }}$ day in basal medium and $4^{\text {th }}$ (inclusion complex of ITC and IPH) and $5^{\text {th }}$ (pure $\beta$-cyclodextrine and inclusion complex of ISC) day in modified media (Figure 1).
The maximum production of antibiotic is $56 \mu \mathrm{g} / \mathrm{cm}^{3}$ in basal medium. The values are 3.4, 2.1, 2.4 and 1.8 times higher in media with inclusion complex of ITC, ISC, $\mathrm{IPH}$ and pure $\beta$-cyclodextrine, respectively (Table 1 ).

Comparing to the results with Schiff base [13] the production of hexaene $\mathrm{H}-85$ and azalomycine $\mathrm{B}$ is higher when $\beta$-cyclodextrine complex with Schiff base is added as a nitrogen source (Table 2). The mechanism of action of tested compounds was not examined. Isatin-Schiff base was used as a nitrogen source due to their similarity with L-tryptophan. This amino acid was already used as a nitrogen source in a basal medium [13]. Since it has a structural similarity with used isatin-Schiff base (an indole moiety), it is obviously why this class of compounds was used for media modification. Those results are connected with fact that inclusion of Schiff bases with $\beta$-cyclodextrine increases their solubility, which has a positive effect on their assimilation by $S$. hygroscopicus $\mathrm{CH}-7$ from media. 
Table 2. Maximum production $\left(\mathrm{C}_{\max }\right)$ and yield of antibiotics $\left(\mathrm{Y}_{\max }\right)$ during the fermentation of $\mathrm{S}$. hygroscopicus $\mathrm{CH}-7$ with Schiff base [13] and inclusion complexes with $\beta$-cyclodextrine

\begin{tabular}{|c|c|c|c|c|}
\hline \multirow{3}{*}{ Nitrogen source } & \multicolumn{2}{|c|}{ Hexaene H-85 } & \multicolumn{2}{|c|}{ Azalomycine B } \\
\hline & $C_{\max }^{H}$ & $Y_{\text {max }}^{H}$ & $C_{\text {max }}^{A}$ & $r_{\text {max }}^{A}$ \\
\hline & $\mu \mathrm{g} / \mathrm{cm}^{3}$ & $\mu \mathrm{g} / \mathrm{g}_{\mathrm{s} . \mathrm{b}}$ & $\mu \mathrm{g} / \mathrm{cm}^{3}$ & $\mu \mathrm{g} / \mathrm{g}_{\mathrm{s} . \mathrm{b}}$ \\
\hline ITC [13] & 372 & 38.75 & 118 & 12.29 \\
\hline $\mathrm{ITC}+\beta-\mathrm{CD}$ complex & 493 & 56.66 & 191 & 21.95 \\
\hline ISC [13] & 293 & 31.50 & 92 & 9.89 \\
\hline $\mathrm{ISC}+\beta-\mathrm{CD}$ complex & 314 & 37.38 & 123 & 14.64 \\
\hline IPH [13] & 329 & 36.15 & 106 & 11.64 \\
\hline $\mathrm{IPH}+\beta-\mathrm{CD}$ (complex) & 417 & 52.12 & 136 & 17.00 \\
\hline
\end{tabular}

\section{The impact of $\beta$-cyclodextrine inclusion complexes with isatin-Schiff bases on $\mathrm{S}$. hygroscopicus $\mathrm{CH}-7$ morphology}

Depending on fermentation conditions, Streptomyces can grow like single filaments, like a branched filaments or small pellets. Small and single pellets favourite the production of secondary metabolites [20]. The production of antibiotics by filamentous microorganisms sometimes depends upon shapes, size and cell branched filaments, which is similar to the pellets (Table 3). Comparing to Schiff bases [13] the morphology of strain has small differences, since they are in the form of pellets and single, free filaments. The highest yield of hexaene $\mathrm{H}-85$ and azalomycine $\mathrm{B}$ was achieved in media with small, dispersive pellets and single filaments. The morphology of Streptomyces hygroscopicus $\mathrm{CH}-7$ is shown in Figure 2.

Table 3. The impact of $\beta$-cyclodextrine inclusion complexes with isatin-Schiff bases on morphology S. hygroscopicus and production of antibiotics

\begin{tabular}{lccc}
\hline & & \multicolumn{2}{c}{ Yield of antibiotics } \\
\cline { 2 - 4 } Nitrogen source & The strain morphology & $\gamma_{\text {max }}^{H}$ & $\gamma_{\text {max }}^{A}$ \\
& & $33 / g_{\text {s.b }}$ & $\mu \mathrm{g} / \mathrm{g}_{\text {s.b }}$ \\
\hline$\beta$-CD (1\%) & Clear, compact pellets, small and short fillamnets & 12.43 \\
ITC+ $\beta$-CD complex & Compact pellets, short, weakly branched fillaments & 56.66 & 21.95 \\
ISC $\beta$-CD complex & Large, compact pellets, long, branched fillaments & 37.38 & 14.64 \\
IPH $\beta$-CD (complex) & Pellets of short single and branched fillaments & 52.12 & 17.00 \\
\hline
\end{tabular}

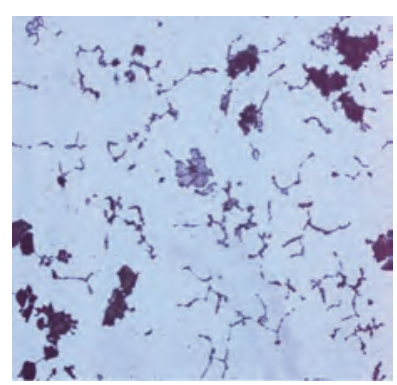

(a)

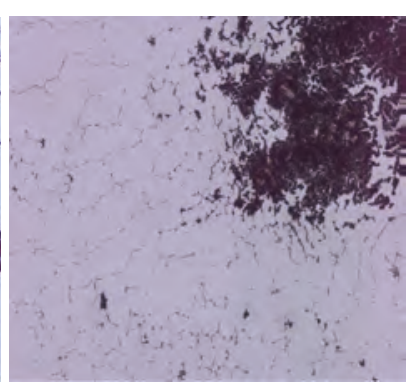

(b)

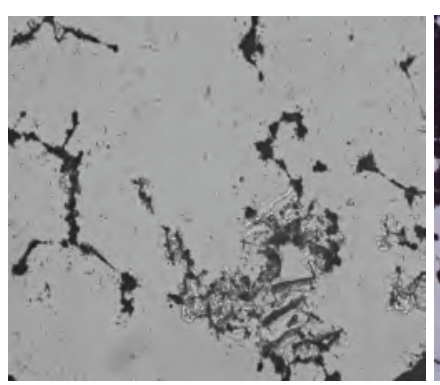

(c)

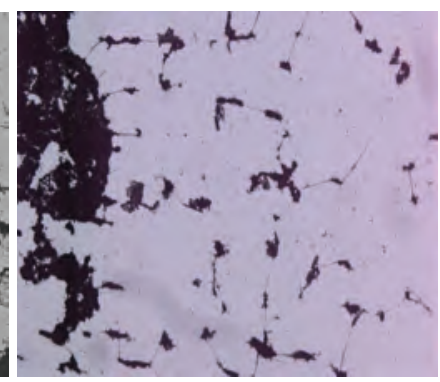

(d)

Figure 2. The morphology of S. hygroscopicus in medium with $\beta$-cyclodextrine inclusion complexes with isatin-Schiff bases. a) $\beta$-Cyclodextrine, b) $\beta$-cyclodextrine inclusion complexes with ITC, c) $\beta$-cyclodextrine inclusion complexes with ISC and d) $\beta$-cyclodextrine inclusion complexes with IPH.

aggregation.

During the fermentation, the nutrient media with $\beta$ cyclodextrine inclusion complexes with isatin-Schiff bases affects the growth of $\mathrm{S}$. hygroscopicus $\mathrm{CH}-7$. The strain in basal medium is in the form of large and single pellets [13]. The strain in modified media is in the form of compact pellets, which formed from short and long,

\section{CONCLUSION}

The antibiotic production by Streptomyces hygroscopicus $\mathrm{CH}-7$ is improved by replacing the soya bean as a nitrogen source with $\beta$-cyclodextrine inclusion complexes with isatin-Schiff base. The media with $\beta$-cyclodextrine inclusion complex of isatin-3-thiosemi- 
carbazone resulted in the maximum antibiotics concentration of $493 \mu \mathrm{g} / \mathrm{cm}^{3}$ for hexaene $\mathrm{H}-85$ and 191 $\mu \mathrm{g} / \mathrm{cm}^{3}$ for azalomycine $\mathrm{B}$. The production of hexaene $\mathrm{H}-85$ and azalomycine is higher when $\beta$-cyclodextrine complex is added as a nitrogen source, comparing to pure isatin-Schiff base. The maximum concentration of hexaene $\mathrm{H}-85$ in medium with inclusion complex of isatin-Schiff base is 1.4-2.3 times higher than the basal medium. The maximum production of azalomycine is 2.1-3.4 times higher in media with inclusion complex of Schiff base. Those inclusion complexes also affect the growth of strain, which is in the form of compact pellets, which formed from short and long, branched filaments. Comparing to Schiff bases the morphology of strain has small differences, since they are in the form of pellets and single, free filaments. Thus, the future experiments will allow the replacement of commercial nitrogen sources with compounds such as inclusion complexes of different Schiff base.

\section{Acknowledgments}

This work has been funded by the Ministry of Education, Science and Technological Development of the Republic of Serbia (Project III 45001).

\section{REFERENCES}

[1] Y. Okami, K. Hotta, Search and Discovery of new antibiotics. In: Actinomycetes in biotechnology, M. Goodfellow, S.T. Williams, M. Mordarski (Eds.), Academic Press, San Diego, CA, 1988, pp. 33-67.

[2] J.I. Prosser, A.J. Tough, Growth mechanisms and growth kinetics of filamentous microorganisms, Crit. Rev. Biotechnol. 10 (1991) 253-274.

[3] Y.G. Bais, T.P. Nimbekar, B.E. Wanjari, S.P. Timande, Isolation of antibacterial compound from marine soli Actinomycetes, IJBAR 3 (2012) 193-196.

[4] F. Marinelli, Antibiotics and Streptomyces: the future of antibiotic discovery, Microbiol. Today (2009) 20-23.

[5] J. Riegdlinger, A. Reicke, H. Zahner, B. Krismer, A.T. Bull, L.A. Maldanado, A. Ward, M. Goodfellow, B. Bister, D. Bischoff, Abyssomicins, inhibitors of the para-aminobenzoic acid pathway produced by the marine Verrucosispora strain AB-18-032, J. Antibiot. 57 (2004) 271-279.

[6] R.D. Charan, G. Schlingmann, J. Janso, V. Bernan, X. Feng, G.T. Carter, Diazepinomicin, A new antimicrobial alkaloid from marine Micromonospora sp., J. Nat. Prod. 67 (2004) 1431-1433.

[7] R.H. Feling, G.O. Buchanan, T.J. Mincer, C.A. Kauffman, P.R. Jensen, W. Fenical, Salinosporamide A: a highly cytotoxic proteasome inhibitor from a novel microbial source, a marine bacterium of the new genus Salinospora, Angew. Chem. Int. Ed. Eng. 42 (2003) 355-357.

[8] J. Vučetić, I. Karadžić, G. Gojgić-Cvijović, E. Radovanović, Improving hexaene $\mathrm{H}-85$ production by Streptomyces hygroscopicus. J. Serb. Chem. Soc. 59 (1994) 973-980.

[9] I. Karadžić, G. Gojgić-Cvijović, J. Vučetić, Hexaene H-85, a hexaene H-85 macrolide complex, J. Antibiot. 12 (1991) 1452-1453.

[10] M.S. Lee, I. Kojima, A.L. Demain, Effect of nitrogen source on biosynthesis of rapamycin by Streptomyces hygroscopicus, J. Ind. Microbiol. Biotech. 19 (1997) 83$-86$.

[11] M.F.V. de Queiroz Sousa, C.E. Lopes, N.A. Pereira Junior, Chemically defined media for production of actinomycin D by Streptomyces parvulus, Braz. Arch. Biol. Technol. 44 (2011) 227-235.

[12] C.K.M. Tripathi, V. Praveen, V. Singh, V. Bihari, Production of antibacterial and antifungal metabolites Streptomyces violaceusniger and media optimization studies for the maximum metabolite production, Med. Chem. Res. 13 (2004) 790-799.

[13] S.B. Ilić, S.S. Konstantinović, D.S. Savić, V.B. Veljković, G. Gojgić-Cvijović, The impact of Schiff bases on antibiotic production by Streptomyces hygroscopicus, Med. Chem. Res. 19 (2010) 690-697.

[14] S.B. Ilić, S.S. Konstantinović, G.Đ. Gojgić-Cvijović, D.S. Savić, V.B. Veljković, The impact of glycerol and some carbohydrates on antibiotic production by Streptomyces hygroscopicus CH-7, Med. Chem. Res. 22 (2013) 934$-937$.

[15] M. Arai, Azalomycins B and F. Two new antibiotics, J. Antibiot., A 13 (1960) 51-56.

[16] S.S. Konstantinović, B.C. Radovanović, S. Sovilj, S. Stanojević, Antimicrobial activity of some isatin-3-thiosemicarbazone, J. Serb. Chem. Soc. 73 (2008) 7-13.

[17] S.S. Konstantinović, Synthesis, structure and animicrobial activity of isatin-Schif base coordination compounds, PhD Thesis, University of Niš, Faculty of Science and Mathematics, 2007.

[18] H. Sawada, T. Suzuki, S. Akiyama, Y. Nakao, Stimulatory effects of cyclodextrins on the production of lankacidingroup antibiotics by Streptomyces species, Appl. Microbiol. Biotechnol. 26 (1987) 522-526.

[19] H. Sawada, T. Suzuki, S. Akiyama, Y. Nakao, Mechanisms of the stimulatory effects of cyclodextrins on lankacidinproducing Streptomyces, Appl. Microbiol. Biotechnol. 32 (2007) 556-559.

[20] W. Yang, A.E. Hartwieg, A. Fang, A. Demain, Effects of carboxymethylcellulose and carboxypolymethylene on morphology of Aspergillus fumigatus NRRL 2346 and fumagillin production, Curr. Microbiol. 46 (2003) 24-27. 


\section{IZVOD}

\section{UTICAJ KOMPLEKSA ŠIFOVIH BAZA SA $\beta$-CIKLODEKSTRINOM NA PRODUKCIJU ANTIBIOTIKA POMOĆU Streptomyces hygroscopicus $\mathrm{CH}-7$}

Slavica B. Ilić ${ }^{1}$, Sandra S. Konstantinović ${ }^{1}$, Gordana Gojgić-Cvijović ${ }^{2}$, Dragiša S. Savić ${ }^{1}$, Vlada B. Veljković ${ }^{1}$

${ }^{1}$ Tehnološki fakultet, Univerzitet u Nišu, Bulevar oslobodjenja 124, 16000 Leskovac, Srbija

${ }^{2}$ IHTM, Univerzitet u Beogradu, Njegoševa 12, p. pr. 815, 11000 Beograd, Srbija

(Naučni rad)

Streptomyces hygroscopicus je soj poznat po produkciji različitih vrsta antibiotika i komercijalno važnih sekundarnih metabolita. Formiranje metabolita je rezultat mikrobioloških procesa u toku fermentacije i zavisi od nivoa biomase mikroorganizma, morfološkog profila kulture, kao i od ekoloških uslova. U cilju povećanja prinosa antibiotika, osnovna hranljiva podloga je redefinisana izmenom izvora azota, tako što su umesto sojinog brašna $\left(10 \mathrm{~g} / \mathrm{dm}^{3}\right)$ dodati kompleksi Šifovih baza sa $\beta$-ciklodekstrinom $\left(10 \mathrm{~g} / \mathrm{dm}^{3}\right)$. Dodatak kompleksa Šifovih baza sa $\beta$-ciklodekstrinom rezultirao je znatno povećanje koncentracije oba antibiotika. Maksimalna koncentracija heksaena H-85 je ostvarena na podlozi sa kompleksom izatin-3-tiosemikarbazona sa $\beta$-ciklodekstrinom i iznosila je $493 \mu \mathrm{g} / \mathrm{cm}^{3}$, dok je za azalomicin B iznosila $191 \mu \mathrm{g} / \mathrm{cm}^{3}$. Povećanje maksimalnih koncentracija antibiotika na podlogama sa kompleksima Schiff-ovih baza je iznosilo 1,4-2,3 puta za heksaen $\mathrm{H}-85$, odnosno 2,1-3,4 puta za azalomicin B, u odnosu na osnovnu podlogu. $U$ toku procesa fermentacije na hranljivim podlogama sa kompleksima Šifovih baza sa $\beta$-ciklodekstrinom, soj raste u obliku kompaktnih peleta, koji se formiraju od kratkih i dugih, razgranatih filamenata.

Ključne reči: Streptomyces hygroscopicus - Šifove baze $\bullet \beta$-Ciklodekstrin $\bullet$ Inkluzioni kompleksi • Produkcija antibiotika 